\title{
Analysis of Fire Spread Prevention Measures in ETICS and Their Influence on Durability
}

\section{Jolanta Šadauskienë*, Algimantas Vasylius}

Faculty of Civil Engineering and Architecture, Kaunas Technology University Studentu Str. 48, LT- 51367, Kaunas, Lithuania

\section{Andrius Buska}

ROCKWOOL UAB, A.Gostauto st. 40B, LT-01112 Vilnius, Lithuania

\section{Juozas Ramanauskas}

Faculty of Civil Engineering and Architecture, Kaunas Technology University Studentu Str. 48, LT- 51367, Kaunas, Lithuania

Institute of Architecture and Construction of Kaunas University of Technology Tunelio Str. 60, LT-44405, Kaunas, Lithuania

*Corresponding author: jolanta.sadauskiene@ktu.lt

$\Gamma$ crossef $h t$ tp://dx.doi.org/10.5755/j01.sace.17.4.16140

In recent years, the external thermal insulation composite system (ETICS) has been applied increasingly in a lot of buildings for energy conservation purposes. However, the increased use of different combustible insulation materials in the ETICS has raised serious fire safety problems. Fires involving this type of ETICS have caused severe damage and loss. Often, the fire spread depends on the thermal material of ETICS. Products of polymeric foams or inorganic fibrous material are commonly used. Practice and case studies of researchers show that involved expanded polystyrene is the most dangerous case of the fire spread. Therefore, it is important to choose the right material. In order to limit fire spread and improve fire safety, fire barriers from were suggested being installed. These measures may include the installation of a noncombustible lintel above each opening in the façade (windows, doors) to prevent flames penetrating the insulating material. Additionally, firestop barriers can be installed horizontally over the entire façade. The fire barriers have to be made of non-combustible materials, such as mineral wool, and are required on every alternate floor in buildings. Energy renovation is a great chance to increase fire safety in buildings. Therefore, the requirements of additional fire safety and prevention are different in Europe. Currently, there are not much data available on the behaviour of different insulation materials (expanded polystyrene and mineral wool) in ETICS and their relevant characteristics during operating life and ETICS durability time. This paper cites the requirements of additional fire prevention in different European countries. Analysis of the physical properties (vapour resistance, thermal transmittance, water absorption and etc.) of the expanded polystyrene and mineral wool products of is presented. This article presents an investigation of thermographic research of building, which was renovated three years ago and has implemented fire barriers.

KEYWORDS: fire safety, external thermal insulation composite system (ETICS), expanded polystyrene (EPS), fire barriers.
JSACE $4 / 17$

Analysis of Fire Spread Prevention Measures in ETICS and Their Influence on Durability

Received 2016/09/01

Accepted after revision $2016 / 10 / 28$

\section{ktu}

Journal of Sustainable Architecture and Civil Engineering Vol. 4/ No. 17 / 2016 pp. 33-44

DOI 10.5755/j01.sace.17.4.16140 (c) Kaunas University of Technology 
Safety is one of the top European Union priorities for a sustainable society. However, accidents, natural disasters, terrorist threats and consequences increase insecurity of the public socio-economic life. Practice shows that fire is one of the most common threats (CTIF 2014). According to the statistical data, $49.5 \%$ of fires happen in residential buildings. Therefore, for public safety, especially in multi-storey residential buildings, fire prevention measures must be taken.

To address this issue, the EU has formed strategic and operational programs lately, in which there are work groups examining cases of fire in buildings, looking for the ways to reduce the likelihood of this threat and making suggestions to the governments. According to the reports submitted, the focus is on the use of polymeric insulation materials produced from petroleum products (expanded polystyrene (EPS), extruded polystyrene (XPS), rigid polyisocyanurate and polyurethane (PIR/ PUR), etc.) in building structures (COST Action FP1404 2015, Beitel and et al. 2014, Werther at al. 2014). According to the references, the greatest threat in terms of uncontrolled spread of fire in buildings is the use of polymeric (plastic) materials for the insulation of buildings, when the walls of the building are insulated using the External Thermal Insulation Composite System (ETICS) containing EPS insulation material or when walls of the building are assembled from multilayer panels with polyurethane insulation material inside (Sowriraajan and Dixit, 2011, Smolka et al, 2015, Deamsa and Rathib, 2011, Nishio et al. 2013).

Despite the fact that EPS contains a fire retardant that slightly reduces its flammability, it does not protect against combustion (Antonatus, 2013, Žukas et al. 2001, Kolbrecki, 2015). An important factor that has a direct impact on the safety of the people during a fire is smoke, flaming droplets and particles (Žukas and Nyderis, 2001). Statistics show that only $18 \%$ of people are killed by direct fire, the others die from the smoke containing harmful substances that are emitted in the combustion process. The smoke also contains poisonous gas that poses a direct threat to life and health of the people who are farther from the source of the fire. Dense smoke makes it difficult to evacuate. Flaming droplets and falling particles can cause injuries and also promote the spread of fire to other floors and surrounding buildings that are distant from the source of fire (Stec and Hull, 2010). The interest in this issue arose in EU countries where human security is one of the sustainability priorities. Most EU Member States have started to use passive fire protection systems with non-combustible insulation inserts between the combustible material layers, that act as a barrier for fire spread (Giletich et al. 2013, Mikkola et al. 2013, Yan et al. 2013, Xin et al. 2013). When such a system is installed, the façade of the building is insulated with EPS slabs, while jambs and horizontal fire protection strips are made from mineral wool (MW) products. Physical properties of the aforementioned insulation materials are different. According to relevant literature, it is known that ETICS durability depends on the compatibility of physical properties of materials contained by this system. Therefore, the aim of this paper is to evaluate the factors influencing the durability of ETICS systems equipped with fire barriers and to identify operation requirements for such systems based on the physical properties of the materials.

Regulations and previous fire safety experiences
To draw a standardisation in security roadmap and to analyse the current security standards landscape in Europe, in May 2011, the European Commission and the EFTA (European Free Trade Association) states launched Mandate M/487 to the European Standardisation Organisations: CEN, CENELEC and ETSI, which has been accepted by CEN, TC 391 "Societal and Citizen Security". The CEN/TS 16850:2015 standard covers public buildings security issues. One of the issues is Chemical, Biological, Radiological and Nuclear defence (CBRNE). The impact of chemical substances emitted in the process of EPS combustion can be compared to hazardous substances and evaluated as a threat. On this basis, a majority of EU Member States drafted and enacted at the national level structural measures used in façade construction, where thermal insulation materials of low reaction to fire class (Euroclass E) are used in order to minimise the 
possible spread of fire and maximize fire safety (Kumm et al. 2013, Lamberto and Cancelliere, 2013, Stromgren et al. 2013, Yoo et al. 2013). Analysis of national regulations of European countries, which allow or prohibit installation of ETICS systems in reaction to fire class B-s3, d0 or lower during refurbishment of residential multi-storey house ( 12 floors / >36 m height) without implementation of additional fire safety elements or testing (e.g. fire barriers, structure solutions, large-scale tests, etc.) was carried out. A mapping was created according to the results of the analysis (Fig. 1).

One of safety elements is perimeter isolation of openings by non-combustible strips. Such a design solution prevents the fire spreading from the inside of the premise to the insulation layer of the ETICS system through the windows and doors. It is recommended (DIBT, 2015) to install the aforementioned fire barriers $200 \mathrm{~mm}$ above the opening and to extend them by $300 \mathrm{~mm}$ away from the opening.

The second safety the element is the installation of horizontal fire barriers in order to prevent fire spreading by the insulation layer of the ETICS system up the façade surface, when the fire source is located outside or appear from the inside of the building. These fire barriers are installed along the perimeter of the entire building; horizontal non-combustible strips are placed between the flammable façade-covering materials. The latter fire prevention measure is important for high buildings (Peng et al. 2013). Horizontal fire safety strip number depends on the building height and the thickness of the insulating layer.

As a result of reviewing normative documents of EU countries, it was determined that there is no common agreement on the use of insulation materials in accordance with fire classification in ETICS. In the European Union, there is a common construction material fire classification assessment methodology, but in many countries, national requirements also apply. For instance, in Lithuania, Spain, Belgium and the Netherlands, in order to determine the façade fire classification of the system, laboratory analysis of reaction to fire tests is enough (ETAG 004). In Germany, the Czech Republic, the United Kingdom, Sweden and elsewhere, whole façade system behaviour during the fire is tested on special conditions by setting "fire" to a large-scale model. Depending on the test method applied or national fire safety requirements, ETICS may comply with a variety of fire safety standards and classifications. For example, currently, in certain countries (e.g., Eastern Europe) insulation products in low reaction to fire classes can be used in exterior wall envelopes of multi-storey buildings that are up to 22-25 m high. In other places, e.g., in Germany, it is forbidden to use combustible insulation material in multi-storey buildings. In a report submitted by the Construction Production Certification Centre (SPCS, 2001) it is mentioned, that when evaluating fire rate of the building, not only separate materials should be evaluated, but the whole system according to the flammability degree. The ETICS fire safety level can be evaluated judging from separate material combustibility feature and their behaviour only during large-scale fire tests (when loads similar to real conditions and wall fragment size are simulated).

In Finland (Mikkola, 2015), it was decided to review the fire safety requirements in accordance with changes happening in a construction sector that was caused by stricter energy efficiency requirements for buildings which are associated with a significantly thicker layer of thermal insulation in ETICS systems or roof structures. Tests carried out by the Finnish fire safety experts have shown that, from 1976 to 2010 , due to the additional exterior wall insulation, fire load per unit of floor area $\left(\mathrm{MJ} / \mathrm{m}^{2}\right)$ increased by $10 \pm 3 \%$ in buildings, where EPS and PIR materials are used for wall insulation; in buildings with MV thermal insulation, such fire load increased by $1.7 \%$.

An even greater increase in the fire load is associated with insulation thickness in flat roof structures: roofing insulation fire load per unit of floor area $\left(\mathrm{MJ} / \mathrm{m}^{2}\right)$ from 1976 to 2010 increased by $35 \%$ in buildings with EPS and PIR insulation, and in buildings with MW insulation such fire load increased by $7 \%$. 
Fig. 1

Mapping of European countries in which national building fire regulations allow or prohibit installation of ETICS systems in reaction to fire class B-s3, d0 or lower

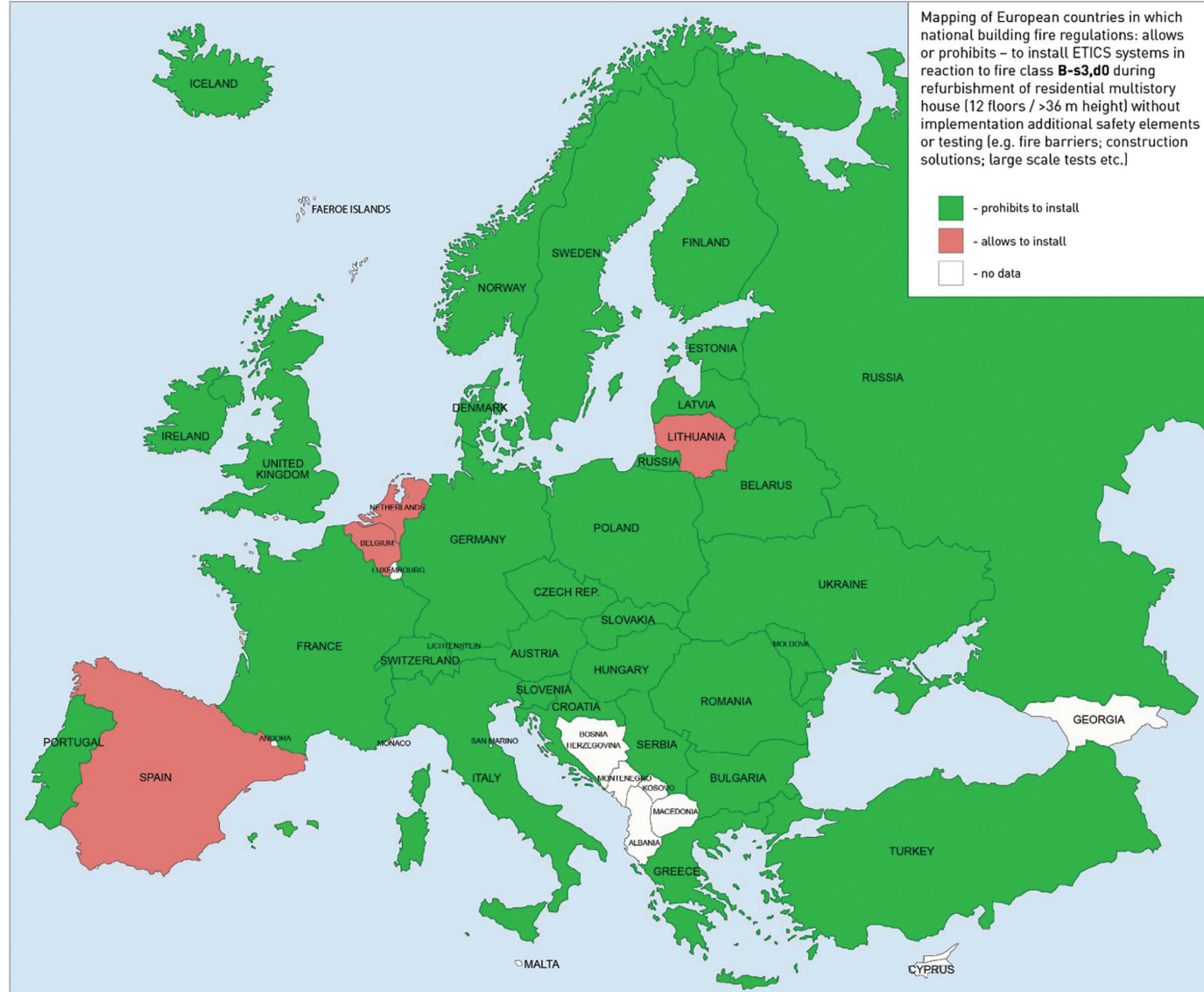

Given the experience of other countries in this respect, it can be said that while thermal requirements for building partitions become stricter, the thermal insulation layer thickness increases, and, therefore, safety in case of fire decreases. Thus, when buildings are renovated, not only energy efficiency requirements must be met, but also interests of safe and sustainable society have to be taken into account and durable operation of the ETICS must be ensured.

In ETICS systems, all materials are usually compatible and tested together. They evenly react to moisture, heat, cold, etc. For this reason, the façade is uniform, stable and durable. This is why ETICS installation is regulated by the Construction Technical Regulation 2.01.10:2007, which indicates that only those ETICS systems should be used for design and installation of constructions which have the European Technical Assessments (ETA) and marked by CE sign. Technical assessment is issued to such a system which has been tested in accordance with ETAG 004 methodology. This methodology includes Mechanical resistance and stability, Safety in a case of fire (separate thermal insulation is evaluated), Hygiene, health and the environment, Safety in use, Protection against noise, Energy economy and heat retention, Aspects of durability and serviceability. This procedure is applied for the ETICS with monolithic thermal insulation materials: mostly EPS or MW. The main parameter of these materials is thermal conductivity coefficient which describes the ability of the material to conduct the heat. It is known that thermal insulation properties of the material can worsen if the material is wet. Therefore, another important property is water steam permeability and water absorption. The humidity state of the ETICS system determines the durability of the system (Sadauskiene and et. al. 2009).

However, there is no methodology that is used to evaluate the compatibility of the combined (from EPS and MW thermal insulation materials) ETICS system made from different materials based on 
the physical properties. Also, in the scientific literature, there are no results of the experiments carried out in this regard. Therefore, the aim of the article is to analyse the impact of the thermal and moisture properties on the durability of the ETICS system.

\section{Measurement of thermal conductivity}

Thermal insulation materials from EPS and MW were investigated in this work. There were analysed EPS slabs of 70 (I variant) and 80 (II variant) classes, MW slabs of chaotic structure (III variant) and vertical orientation structure (IV variant).

The thermal conductivities of the thermal insulation materials (EPS and MW) were measured with a thermal conductivity measurement apparatus according to the requirements of LST EN 12667, which has the central measuring part with the area of $250 \times 250 \mathrm{~mm}$, the temperature gradient through a specimen approximately $20^{\circ} \mathrm{C}$, the temperature of the horizontal hot bottom plate $20^{\circ} \mathrm{C}$, the temperature of the horizontal cold top plate approximately $0^{\circ} \mathrm{C}$, the direction of the heat flow is vertical, going upwards. Fig. 2 presents this test.

In order to evaluate the significance of the thermal conductivity properties difference of the EPS and MW, to get the thermal conductivities study results were processed using SPSS package, using one-factor dispersive ANOVA statistical analysis, which aims - to determine whether the average of the dependent variable interval $(\mu)$ in the different samples are significantly different. The sample size $n$ was 15 . Statistical hypothesis when the significance level $\alpha=0.05$ is formulated as follows:

$$
\left\{\begin{array}{l}
\text { HO: } \mu 1=\mu 2=\mu 3=\mu 4, \\
\text { Ha: at least two differ average. }
\end{array}\right.
$$

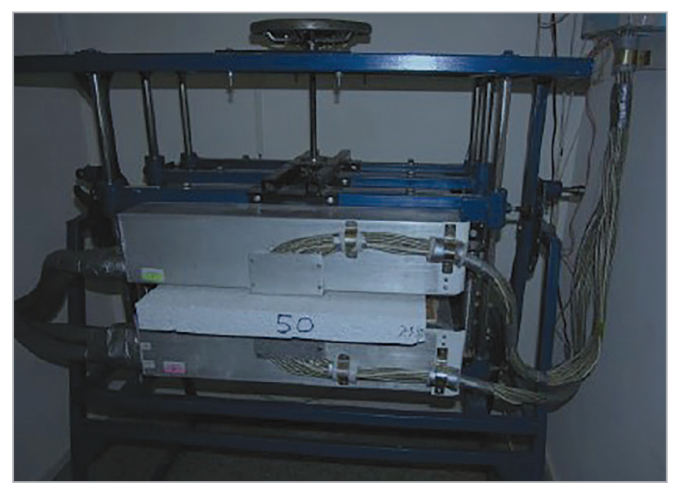

The null hypothesis $\mathrm{HO}$ means that the factor does not affect, i.e. thermal conductivity properties of a wall are not influenced by the thermal insulation material type. The alternative

hypothesis $\mathrm{Ha}$ - thermal conductivity properties of a wall are influenced by the thermal insulation material type. Using SSPS statistical package, ANOVA results are presented by $p$-value. $H O$ is rejected (averages differ), when $p<\alpha$. HO is not excluded (the difference was not found), when $p \geq \alpha$.

\section{ETICS humidity state evaluation}

In order to check the moisture state of the expanded clay wall, that is next to the thermal insulating layer and to evaluate the impact of the insulation material to the moisture state of the wall, natural experiments were carried out, during which a multi-storey residential buildings that have been operated for three years and are insulated by ETICS systems with different $120 \mathrm{~mm}$ thick thermal insulation slabs (MW and EPS) were examined. Moisture content was determined in 7 points: in a place where the thin layer of plaster and thermal insulation material come into contact; in the middle of the thermal insulation layer; in a place where glue and thermal insulation material come into contact; in the middle of the glue layer; in a place where expanded clay wall and the glue layer comes into contact; $60 \mathrm{~mm}$ deep into the expanded clay wall from the outer side; $120 \mathrm{~mm}$ deep into the expanded clay wall from the outer side (Fig. 4). Samples for moisture content evaluation were taken approximately at the level of the ground floor.

Using the WUFI computer program in which is integrated method of EN ISO 13788, the changes of the moisture state in junction plane of the insulation layer made from EPS and MW and supported wall over time. 


\section{Durability evaluation test}

In order to evaluate the durability of the combined ETICS systems, a thermographic, visual and population survey researches have been conducted. For the research, a multi-storey residential building that was renovated in 2012 by installing the ETICS system with EPS insulation material and additional fire barriers in the zone of around openings using mineral wool strips (Fig. 3) was selected. The thick of thermal insulations layer was $150 \mathrm{~mm}$.

Fig. 3

The investigated building with the ETICS system with installed the add fire safety measure (fire barriers from MW insulation)

\section{Results and discussion}
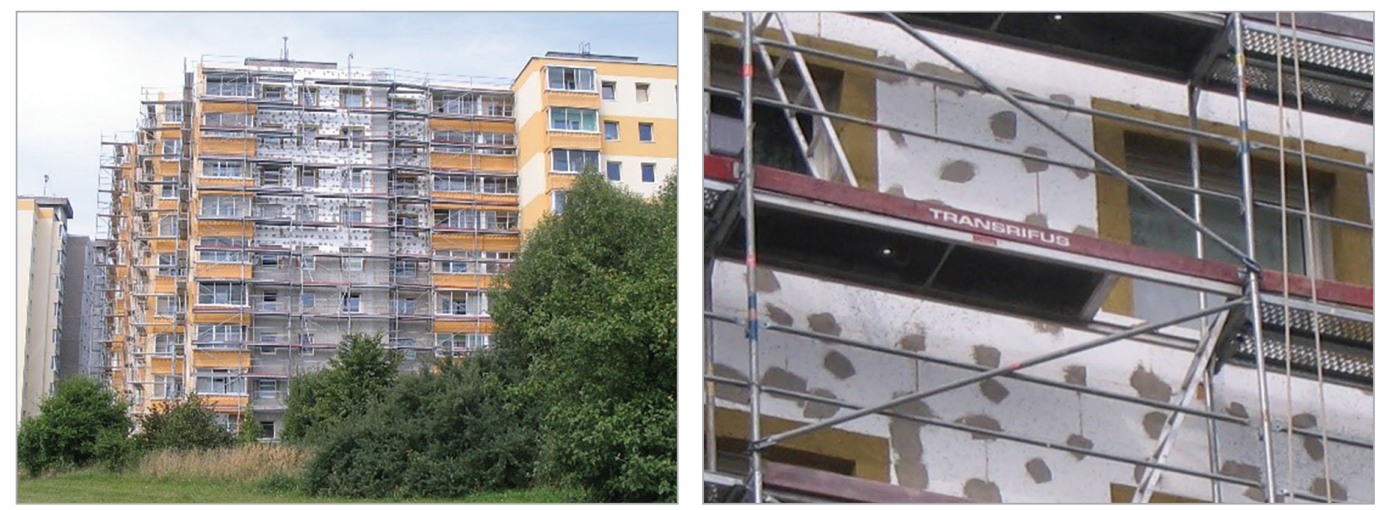

The thermographic survey was performed in order to identify defective parts of the investigated building. Qualitative detection of thermal irregularities in building envelopes (LST EN 13187) based on Infrared method was used for this purpose. This survey was carried out with the infrared camera "ThermaCAM B640", which creates electrical signals according to the infrared wavelength and intensity. Electrical signals are compared with temperature etalon and temperature of the measured surface is calculated. The accuracy of the device is $2 \%$ or $2{ }^{\circ} \mathrm{C}$. The infrared camera converts thermal heat radiation to the colour image, i. e. thermogram, which is used to detect building envelope defects.

All thermographic investigations were made during the winter period. The difference between the indoor and the outdoor air temperature was at least $20^{\circ} \mathrm{C}$.

Visual tests were used to determine the external defects of the ETICS system, irregularities, etc.

The aim of the population survey was to evaluate the climate and air movement sensation due to the installation of the combined thermal insulation materials. 20 residents from different apartments of one building were interviewed.

\section{Thermal conductivity of thermal insulation materials}

The results of the thermal conductivity investigation are provided in Table 1, which shows average value $x$ of each test of the thermal insulation material, the variance $s^{2}$ and standard deviation $s$. Variance and standard deviation indicate the data dispersion about an average value. The established thermal conductivity values are a random variable and their implementations are distributed about the real value of the parameter. Therefore is important to know an interval of thermal conductivity values depending on the type of thermal insulation material. Confidence interval set at 0.95 probability.

The statistical significance of differences of the thermal conductivity of different thermal insulation materials is given in Table 2 .

Statistical results of the thermal conductivity investigations show that the type of thermal insulation material (EPS or MW) does not make a statistically significant influence to thermal conduction through the walls. 


\begin{tabular}{c|c|c|c|c}
\hline The variant of sample & $x$ & $s^{2}$ & $s$ & Confidence interval \\
\hline I & 0.0380 & $3.2 \cdot 10^{-7}$ & $5.7 \cdot 10^{-4}$ & $0.0375-0.0384$ \\
\hline II & 0.0370 & $9.9 \cdot 10^{-7}$ & $9.9 \cdot 10^{-4}$ & $0.0365-0.0374$ \\
\hline III & 0.0344 & $5.9 \cdot 10^{-8}$ & $2.4 \cdot 10^{-4}$ & $0.0341-0.0346$ \\
\hline IV & 0.0397 & $4.5 \cdot 10^{-8}$ & $2.1 \cdot 10^{-4}$ & $0.0394-0.0401$ \\
\hline
\end{tabular}

\begin{tabular}{|c|c|c|c|}
\hline $\begin{array}{l}\text { The variant } \\
\text { of sample }\end{array}$ & Statistic & $p$-value & Outcomes \\
\hline I & 0.254 & 0.682 & $\begin{array}{l}0.682>0.05 \text {. Therefore, the hypothesis about equality of the averages } \\
\text { of the dependent variable interval }(\mu) \text { is not excluded. The averages of } \\
\text { thermal conductivity do not differ a statistically significantly. The value } \\
\lambda \text { does not depend on the type of thermal insulation material. }\end{array}$ \\
\hline II & 3.971 & 0.081 & $\begin{array}{l}0.081>0.05 \text {. Therefore, the hypothesis about equality of the averages } \\
\text { of the dependent variable interval }(\mu) \text { is not excluded. The averages of } \\
\text { thermal conductivity do not differ a statistically significantly. The value } \\
\lambda \text { does not depend on the type of thermal insulation material. }\end{array}$ \\
\hline III & 3.991 & 0.116 & $\begin{array}{l}0.116>0.05 \text {. Therefore, the hypothesis about equality of the averages } \\
\text { of the dependent variable interval }(\mu) \text { is not excluded. The averages of } \\
\text { thermal conductivity do not differ a statistically significantly. The value } \\
\lambda \text { does not depend on the type of thermal insulation material. }\end{array}$ \\
\hline IV & 0.06 & 0.812 & $\begin{array}{l}0.812>0.05 \text {. Therefore, the hypothesis about equality of the averages } \\
\text { of the dependent variable interval }(\mu) \text { is not excluded. The averages of } \\
\text { thermal conductivity do not differ a statistically significantly. The value } \\
\lambda \text { does not depend on the type of thermal insulation material. }\end{array}$ \\
\hline
\end{tabular}

\section{Evaluation of the moisture content of the ETICS}

When the moisture content of the natural ETICS systems containing EPS and MW thermal insulation materials determination research was carried out, it was determined that the moisture content of expanded clay and insulation material did not exceed the normal limits (Fig. 4). It was also found that the outer surface of the expanded clay under the MW slabs was drier than under EPS slabs.

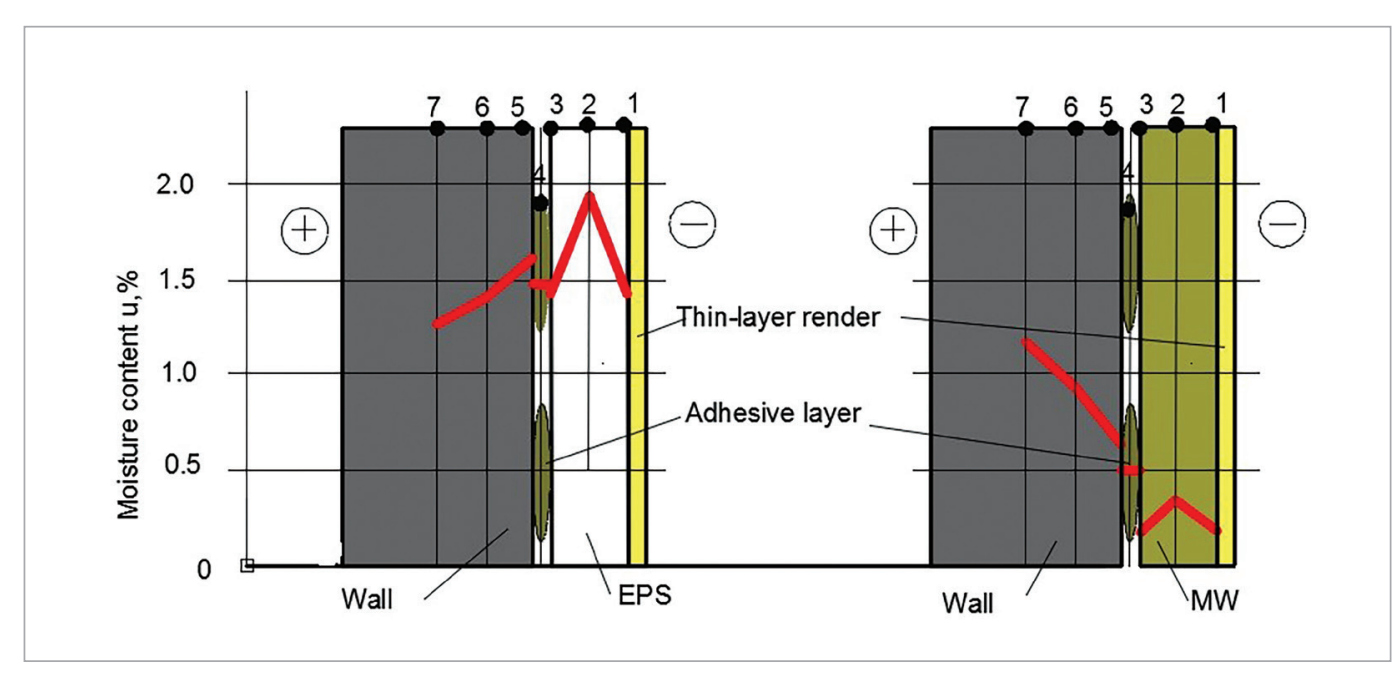

Fig. 4

Moisture content of ETICS with different thermal insulation materials

The statistical significance
Table 1

Statistical data of the thermal conductivity of materials

\section{of differences of the thermal conductivity of different thermal insulation materials \\ Table 2}


When evaluating the interlayer of the thermal insulation material and thin-layer plaster, it was found that the most favourable moisture behaviour is that of a system with EPS. However, when a thin layer of water vapour permeable plaster is used in systems with MW thermal insulation material, moisture behaviour in the interlayer does not exceed the normal limits.

Water vapour permeability values of EPS and MW products differ, therefore, the wall drying conditions vary. When evaluation the changes of moisture content in time in ETICS systems with different thermal insulation materials, it can be stated that the drying conditions are more favourable in the ETICS system with MW insulation materials (Fig. 5). The results show that the influence of the moisture permeability coefficient of the thermal insulation material is more important when the structure is drying, and not getting wet (Ramanauskas and Stankevičius, 2000).

\section{Fig. 5}

The moisture content of the wall connected to the thermal insulation layer

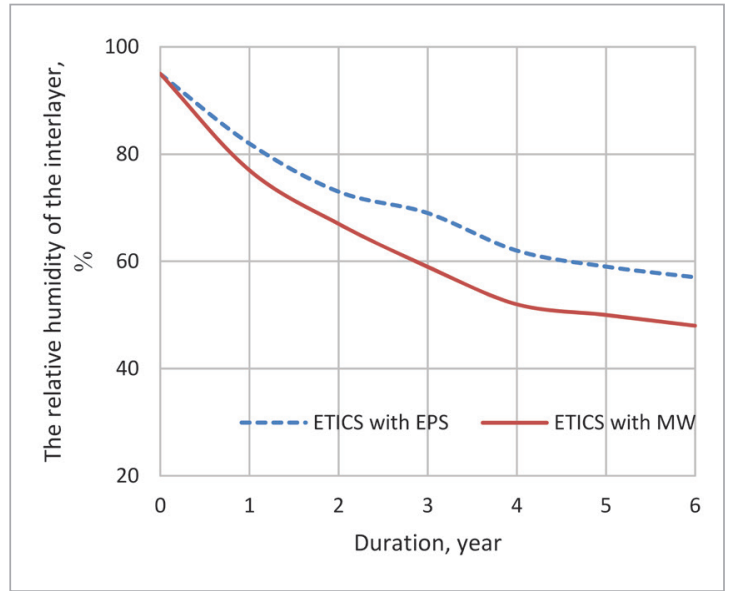

After reviewing the research results, it can be stated that the moisture condition of the ETICS system is influenced not by the thermal insulation material type, but by the type of external thin layer of plaster used, based on the water vapour permeability and absorption properties (Šadauskienè and Šeduikyte, 2013). If the thin layer of plaster is impervious to water vapour, it can prevent the wall from drying. Then the moisture will accumulate in the wall. When the wall gets cold, it will expand, and the thin layer of plaster will start cracking. Due to the cyclically repeated

freezing-heating process, the wall may be damaged. That system will not be durable.

The water vapour permeability of thin layer render in the ETIC which is based on EPS shall be less than $20 \mathrm{~g} /\left(\mathrm{m}^{2} \mathrm{~d}\right)$ (EN 13499). The water vapour permeability of thin layer render in the ETIC which is based on MW shall be less than $40 \mathrm{~g} /\left(\mathrm{m}^{2} \mathrm{~d}\right)$ (EN 13500). However, in both cases (using EPS and MW thermal insulation layers), the correctly designed structures and the used of certified ETICS that have technical certificates, the influence of the moisture content on the system durability will not be significant. This means, that the installation of fire barriers in the ETICS systems with EPS products or covering the openings with MW, it is necessary to choose the exterior thin layer of plaster that is permeable to water vapour. Then, the ETICS system will be durable and will ensure the safety of the society and residents in case of fire.

\section{Thermographic, visual and population survey research}

During the visual research, no defects or surface decay were noticed in the outer thin layer of plaster (Fig. 6).

Fig. 6

Results of the visual research
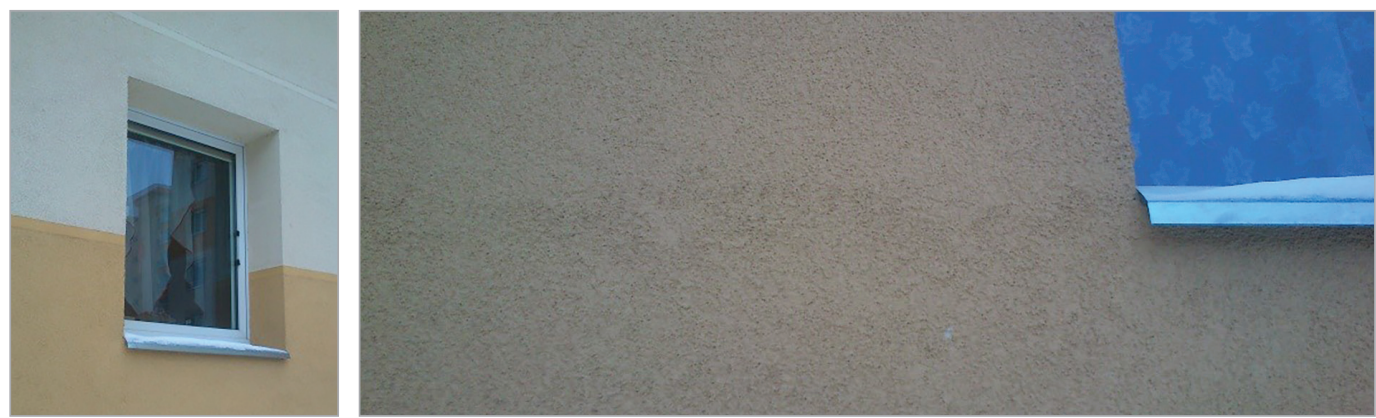

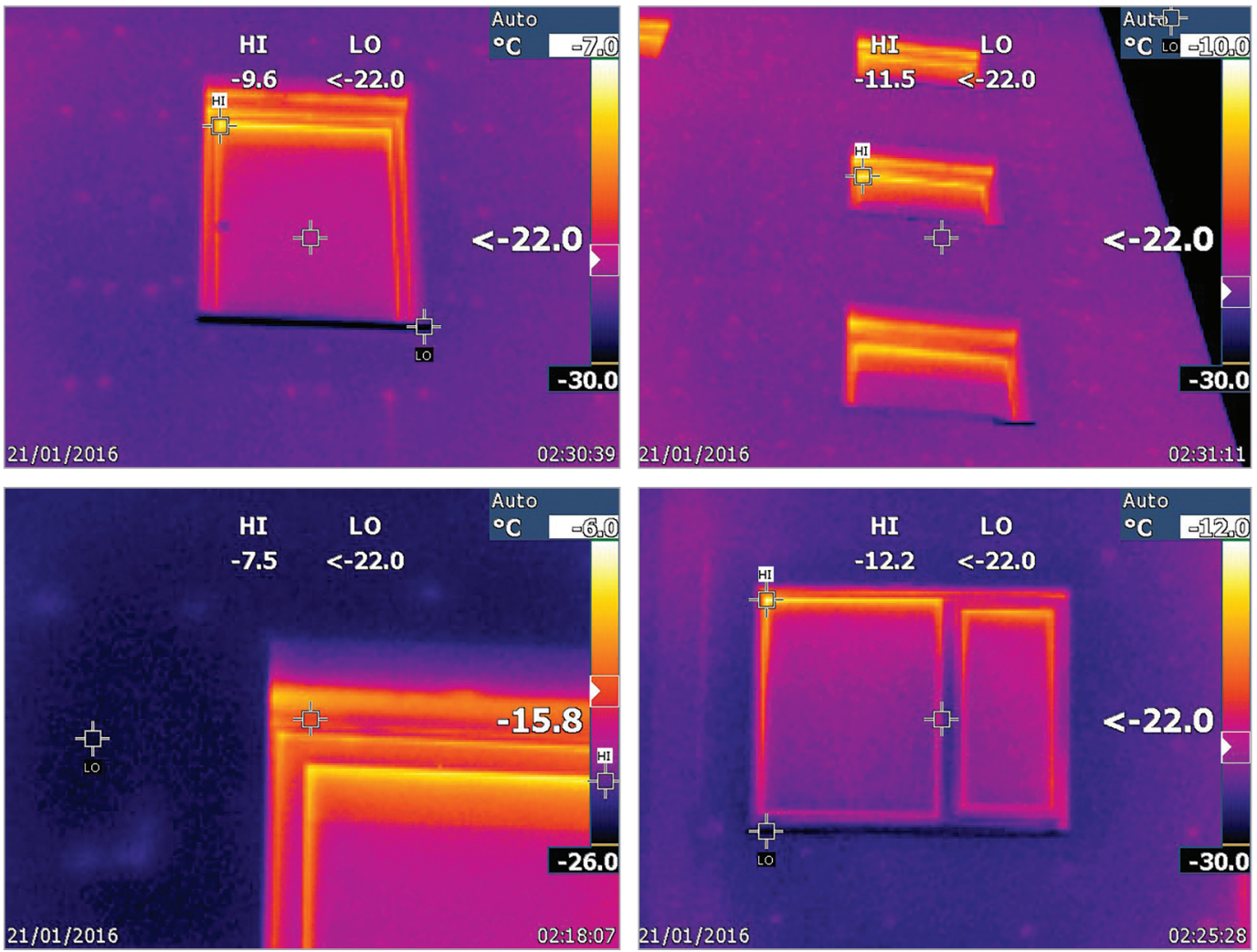

Fig. 7

Results of the thermographic research in the jamb zone outside of the building

Positive results were obtained after the thermographical research as well (Fig. 7). The effect of thermal bridges is clearly visible through thermal insulation layer fasteners and window frames in the thermographic pictures. This shows that different low thermal conductivity values of EPS and MW insulation materials do not have any influence on the functional operation and durability of the ETICS system.

The results of the population survey show that $95 \%$ of the population is satisfied with the installation of the combined system into ETICS; they did not notice any defects and did not feel cold next to the MW and EPS slab contact zones at the wall. And they are confident that such a system is safer in a case of a fire. $5 \%$ of residents did not answer this question.

The results of the thermographic research which evaluated the jamb zone from the inside of the building (Fig. 8) show that the leaks are positioned next to the contact zone of the window frame and the wall, and thermal bridges form in this place. However, MW and EPS slabs contact zones are not identified due to the difference in surface temperature.
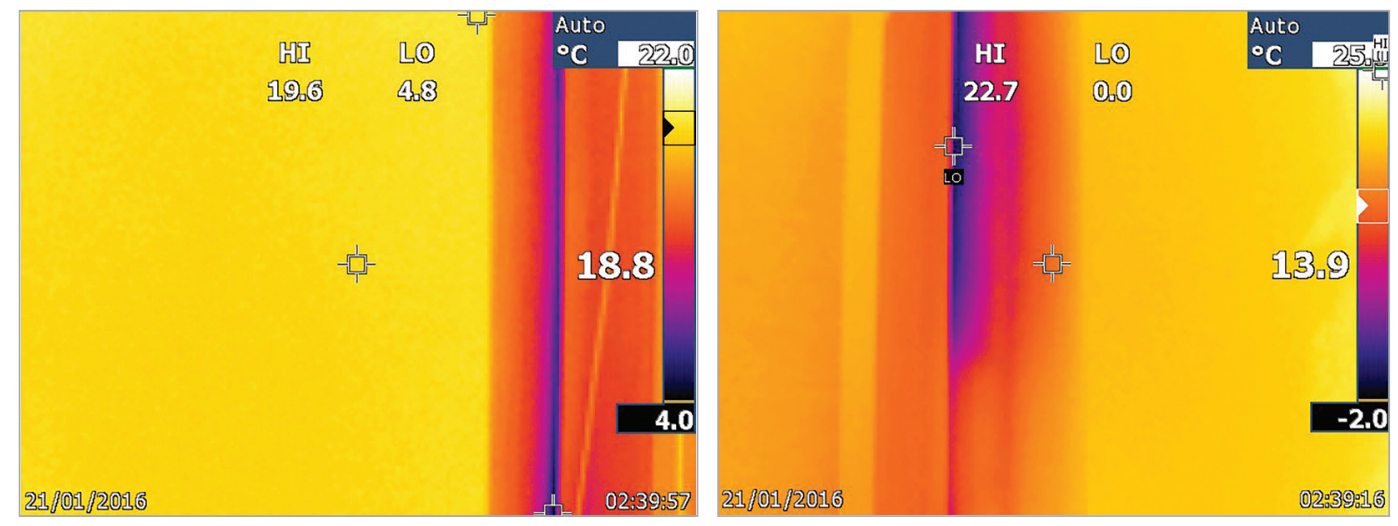

Fig. 8

Results of the thermographic research in the jamb zone inside the building 
In order to implement the public and residential safety policy in the EU, the use of fire safety preventive measures in the ETICS systems should be legalised and a harmonised standard corresponding to a real fire scenario should be adopted. Passing on the advanced international experience and harmonisation of standards would contribute to energy, public and environmental safety policy not only in Lithuania but also in the European context.

In multi-storey residential buildings with exterior walls that are insulated with the ETICS system containing a low reaction to fire class insulation material, passive fire protection barriers made from non-combustible construction products should be installed.

Research has shown that the ETICS systems with polymeric foam insulation material and installed fire safety measures (fire barriers) from non-combustible thermal insulation construction materials (mineral wool) can be used when the water vapour permeability of the exterior thin layer of plaster is sufficient to ensure the favourable moisture behaviour in the wall.

In operated buildings that have walls insulated using ETICS with EPS products and installed MW fire barriers, no external defects or changes in thermal properties in real operating conditions were detected.

The results show that different low thermal conductivity values of EPS and MW insulation materials do not have any influence on the general functional operation and durability of the ETICS system.

\section{References}

Antonatus E. Fire safety of etics with EPS material properties and relevance for fire safety during transport, construction and under end use conditions in external thermal insulation component systems. MATEC Web of Conferences 9, 02008; 2013. DOI: 10.1051/matecconf/20130902008. https://doi. org/10.1051/matecconf/20130902008

Beitel J. J., Fischer M. D., Hirschler M. M., Ross L. A. Questions and Answers on Issues Raised During CA AB 127 Working Group. December 2014. Available from internet: http://osfm.fire.ca.gov/codedevelopment/pdf/wgfsbim/QandAReport.pdf

CEN/TS 16850:2015. Societal and Citizen Security - Guidance for managing security in healthcare facilities.

Daemsa D., Rathib D. Fire Performance of New Polyurethane Building Insulation Applications in India. Pro-ceedings of Fire Science and Technology Research \& its Implementations. 2011; 436-444.

DIBT. Constructive designs to improve the reaction to fire performance of ETICS with EPS insulation rat-ed as schwerentflammbar1. Section ॥ 1 Plastics Construction, Facades Version: 27 May 2015. https://www.dibt.de/en/Departments/data/ II1_Information_ETICS_with_EPS_insulation_ May_2015_EN.pdf

EN ISO 13788. Hydrothermal performance of building components and building elements. Internal sur-face temperature to avoid critical surface humidity and interstitial condensation. Calculation methods. European Committee for Standardization. 2001.
EN 13499. Thermal insulation products for buildings. External thermal insulation composite systems (ETICS) based on expanded polystyrene. Specification. European Committee for Standardization. 2003.

EN 13500. Thermal insulation products for buildings. External thermal insulation composite systems (ETICS) based on mineral wool. Specification. European Committee for Standardization. 2003.

Fire Safe Use of Bio-Based Building Products. Proceedings of the 1st European Workshop Fire Safety of Green Buildings, COST Action FP1404 Berlin, Germany 6 - 7 October 2015.

Giletich A. N., Kosachev A. A., Kosachev A. A. Fire hazard analysis of façade systems in reconstructing buildings. MATEC Web of Conferences 9, 05001, 2013. DOI: 10.1051/matecconf/20130905001. https://doi.org/10.1051/matecconf/20130905001

ISO EN 12667. Thermal performance of building materials and products - Determination of thermal re-sistance by means of guarded hot plate and heat flow meter methods - Products of high and medium thermal resistance.

Jensen $G$. Fire spread modes and performance of fire stops in vented façade constructions - overview and standardization of test methods. MATEC Web of Conferences 9, 02002, 2013. DOI: 10.1051/matecconf/20130902002.

https://doi.org/10.1051/matecconf/20130902002

Kolbrecki A. Model of fire spread out on outer building surface. Technical Sciences. 2015; 63(1):56- 
69. DOI: 10.1515/bpasts-2015-0015 https://doi. org/10.1515/bpasts-2015-0015

Kumm M., Söderström J., Lönnermark A. EPS insulated façade fires from a fire and rescue perspective. MATEC Web of Conferences 9, 05003, 2013. DOI: 10.1051/matecconf/20130905003 https://doi. org/10.1051/matecconf/20130905003

Lamberto M., Cancelliere P. The Italian National Guidelines for the fire safety of facades. MATEC Web of Conferences 9, 01005, 2013. DOI: 10.1051/ matecconf/20130901005 https://doi.org/10.1051/ matecconf/20130901005

Mikkola E. Fire loads and fire safety in buildings. Part 2: Protection of fire loads within building structures. Research report. 2015.

Nishio Y., Yoshioka H., Noguchi T., Ando T., Tamura M.. Experimental study on fire propagation over com-bustible exterior facades in Japan. MATEC Web of Conferences 9, 04001; 2013. DOI: 10.1051/ matecconf/20130904001. https://doi.org/10.1051/ matecconf/20130904001

Peng L., Ni Z., Huang X. Review on the fire safety of exterior wall claddings in high-rise buildings in China. Procedia Engineering 2013, 62:663 - 670. https://doi.org/10.1016/j.proeng.2013.08.112

Ramanauskas J., Stankevičius V. Pastatų sienu šiltinimo sistemu atsparumas klimato poveikiams [Build-ing wall insulation systems resilience to climate impacts], Monograph. Kaunas: Technologija, 2000. p. 142.

Sadauskienè J., Stankevicius V., Bliudzius R., A.Gailius. The Impact of the Exterior Painted Thin-Layer Ren-der's Water Vapour and Liquid Water Permeability on the Moisture State of the Wall Insulating System. Construction and Building Materials. 2009, 23:2788-2794.https://doi.org/10.1016/j.conbuildmat.2009.03.010

Šadauskienè J., Šeduikytè L. The Influence of Moisture Behaviour on Durability of Renovated External En-velopes. International conference, Innovative Materials, Structures and Technologies, 2013; 8 Novem-ber, Riga, Latvia.

Smolka M., Mózer V., Tofito P. Fire Performance of Composite-Panel Separation Walls. Applications of Structural Fire Engineering, 2015; 15-16 October, Dubrovnik, Croatia. DOl:http://dx.doi.org/10.14311/ asfe.2015.062 https://doi.org/10.14311/asfe.2015.062

Sowriraajan A. V., Dixit C. S. B. Improvement of Fire Safety in Rooms with Existing Expanded Polystyrene Roof Insulation. Proceedings of Fire Science and Technology research \& its Implementations, 2011; 120-130.

SPSC. Subsistence fire tests of field lightweight roof structures and insulated from the outside façade constructions. Test report. [Natūriniai lengvų stogo konstrukciju ir iš lauko apšiltintų fasadų konstrukcijų natūriniai gairiniai bandymai. Bandymų ataskaita]. 2001.

Stec A., Hull T. R. Assessment of the fire toxicity of building insulation materials. Energy and Buildings, 2011 43(2-3):498-506.

STR 2.01.10:2007. Išorinès tinkuojamos sudètinès termoizoliacinès sistemos [External Thermal Insula-tion Composite System], Vilnius, Ministry of Environment of Republic of Lithuania, 2007.

Strömgren M., Albrektsson J., Johansson A., Almgren E. Comparative analysis of façade regulations in the Nordic countries. MATEC Web of Conferences 9, 01003, 2013. DOI: 10.1051/matecconf/20130901003 https://doi.org/10.1051/matecconf/20130901003

Werther N., Friquin K., Tulamo T. SmartTES. Innovation in timber construction for the modernization of the building envelope. Fire safety. 2014; Book 5. Available from internet: http://www.tesenergyfacade.com/downloads/smarttes_b5_Firesafety.pdf

World Fire Statistics. CTIF 2014. Nr. 19. Available from internet: https://www.ctif.org/sites/default/ files/ctif_report19_world_fire_statistics_2014.pdf

Xin H., Zhaopeng N., Lei P., Ping Z. Experimental study of fire barriers preventing vertical fire spread in ETISs. MATEC Web of Conferences 9, 04003, 2013. DOI: 10.1051/matecconf/20130904003 https://doi. org/10.1051/matecconf/20130904003

Yan Z., Zhao Ch., Liu Y., Deng X., Ceng X., Liu S., Lan B., Nilsson R., Jeansson S. Experimental study and advanced CFD simulation of fire safety performance of building external wall insulation system. MATEC Web of Conferences 9, 03005, 2013. DOI: 10.1051/ matecconf/20130903005 https://doi.org/10.1051/ matecconf/20130903005

Yoo Y. H., Chae S. U., Kim H. Y., Kim W. H. Study on prevention of spread of vertical fire along finishing materials for external wall of high-rise buildings. MATEC Web of Conferences 9, 05004, 2013. DOl: 10.1051/matecconf/20130905004 https://doi. org/10.1051/matecconf/20130905004

Žukas A., Mačiulaitis R., Beganskienè A., Kareiva A. Polistireno degimo produktu kokybinis jvertinimas [Qualitative assessment of combustion of polystyrene products]. Chemine technologija 2001; 4(21): 56-61.

Žukas A., Nyderis A. Degimo produktų gaisrinio pavojingumo vertinimas: dūmų susidarymas ir toksišku-mas [The assessment of fire hazard of combustion products: smoke generation and toxicity]. Modern Building Materilals, Structures and Techniques. The 7th International Conference. Vilnius, Lithuania, May 16-18, 2001. 


\section{About the authors \\ JOLANTA \\ ŠADAUSKIENĖ \\ Associated professor \\ Kaunas University of \\ Technology, Faculty \\ of Civil Engineering \\ and Architecture, \\ Department of Building \\ Energy Systems}

\section{Main research area}

energy efficiency of buildings, heat transfer and thermal insulation, building envelope humidity behavior

\section{Address}

Studentu st. 48,

LT-44403, Kaunas,

Lithuania

Tel. +370 37350453

E-mail: jolanta.

sadauskiene@ktu.lt

\section{ANDRIUS}

BUSKA

Doctor, a technical manager

Company „ROCKWOOL“

Main research area

thermal properties of materials, heat transfer and thermal insulation

\section{Address}

A. Goštauto st. 40B, LT01112 Vilnius, Lithuania Tel. +370 52126024

E-mail: andrius.buska@ rockwool.com

\section{ALGIMANTAS VASYLIUS}

\section{Doctor, lector}

Kaunas University of

Technology, Faculty of Civil Engineering and Architecture, Department of Building Energy Systems

\section{Main research area}

IT simulation, building modelling

\section{Address}

Studentu st. 48 , LT-44403, Kaunas, Lithuania Tel. +370 37350450 E-mail: algimantas. vasylius@ktu.lt
JUOZAS

RAMANAUSKAS

Researcher, associated professor

The Laboratory of Building Physics at the Institute of Architecture and Construction Kaunas University of Technology, Faculty of Civil Engineering and Architecture, Department of Building Materials

\section{Main research area}

energy efficiency of buildings, heat transfer and thermal insulation, building envelope humidity behaviour

\section{Address}

Tunelio st. 60, LT-44405, Kaunas, Lithuania Tel. +370 37350779 E-mail: juozas. ramanauskas@ktu.lt 